


\title{
IMPLEMENTASI BUDAYA \\ KORPORAT DAN ORGANISASI
}

\author{
Dian Arlupi Utami
}

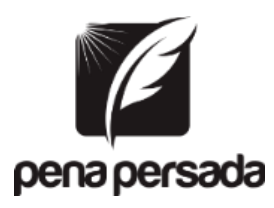

PENERBIT CV. PENA PERSADA 


\title{
IMPLEMENTASI BUDAYA \\ KORPORAT DAN ORGANISASI
}

\author{
Penulis: \\ Dian Arlupi Utami \\ Editor \\ Safrinal \\ ISBN: \\ Design Cover: \\ Retnani Nur Briliant \\ Layout: \\ Hasnah Aulia

\section{Penerbit CV. Pena Persada} \\ Redaksi: \\ Jawa Tengah \\ Anggota IKAPI \\ All right reserved \\ Cetakan pertama: 2021
}

Jl. Gerilya No. 292 Purwokerto Selatan, Kab. Banyumas

Email : penerbit.penapersada@gmail.com

Website: penapersada.com Phone: (0281) 7771388

Hak Cipta dilindungi oleh undang-undang. Dilarang memperbanyak karya tulis ini dalam bentuk apapun tanpa izin penerbit 


\section{KATA PENGANTAR}

Puji syukur penulis panjatkan kehadirat Allah SWT karena atas perkenan-Nya semata penulis dapat menyelesaikan penulisan Buku Referensi ini, sebagai wujud pengabdian penulis kepada Allah SWT sekaligus pengabdian kepada ilmu pengetahuan.

Buku Referensi yang berjudul IMPLEMENTASI BUDAYA KORPORAT DAN ORGANISASI ini merupakan himpunan materi perkuliahan yang disajikan secara komplit baik teori maupun implementasinya. Harapan penulis dengan adanya Buku ini agar di dalam proses belajar mengajar pada perkuliahan mahasiswa ataupun digunakan masyarakat umum dan pemerhati kajian Budaya Organisasi dapat mudah disajikan, lebih mudah dipahami mahasiswa dan diharapkan dapat meningkatkan hasil belajar mahasiswa.

Buku ini terdiri dari 5 ( lima ) bab, yang merupakan wujud dari kerja sama dengan berbagai pihak. Penulis mengucapkan Terima Kasih kepada pihak-pihak yang telah ikut membantu.

Terselesaikannya buku ini. Apabila di dalam buku ini terdapat banyak kekurangan, penulis pandang sebagai sesuatu yang wajar dan akan menjadi perhatian penulis di masa yang akan datang. Saran dan masukan yang akan datang dari pembaca dan pemakai buku ini akan diterima dengan segala senang hati.

Surabaya, Agustus 2021

Penulis 


\section{DAFTAR ISI}

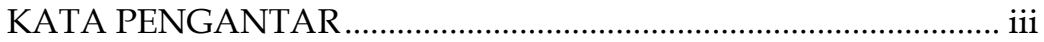

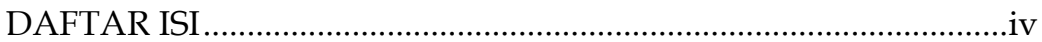

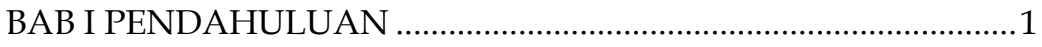

BAB II GAMBARAN UMUM PT. TELKOM INDONESIA .............11

A. Sejarah Singkat PT. TELKOM INDONESIA ............................11

B. Korporat The Telkom Indonesia................................................12

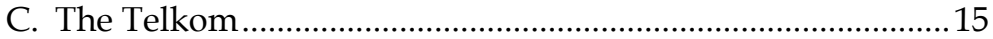

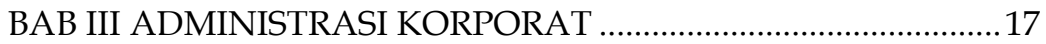

A. Administrasi Publik dan Dinamika Kelompok ......................17

B. Perkembangan Ilmu Admnistrasi dalam Perspektif New Public Management, Governance dan New Public Service 29

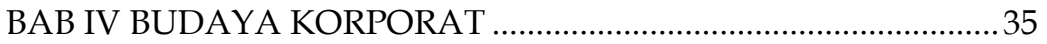

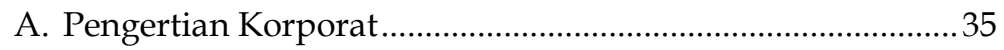

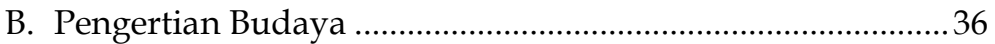

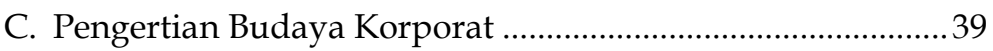

D. Fungsi Budaya Korporat ........................................................... 40

E. Pentingnya Memahami Budaya Korporat ................................ 43

F. Tingkatan Budaya Korporat..................................................... 44

G. Kepemimpinan dan Unsur - Unsur Budaya dalam Sebuah

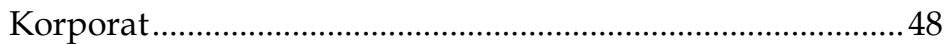

H. Upaya Memelihara dan Memperkuat Budaya Korporat .....68

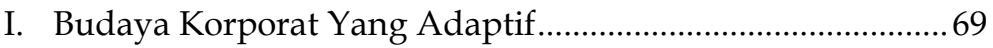

J. Implementasi Budaya Korporat The TELKOM.......................70 BAB V LANGKAH TELKOM MENUJU PEMENANGAN

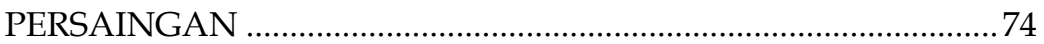

A. Rentangkan Tujuan Keluar Batas Yang Normal (Stretch The

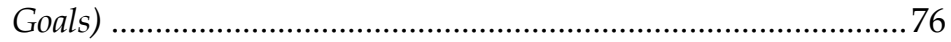

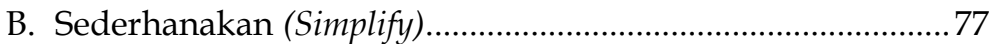

C. Libatkan Setiap Orang (Involve Everyone) ................................ 79

D. Kualitas Adalah Pekerjaan Saya (Quality Is My Job) ...............80

E. Imbali Para Pemenang (Rewards The Winners)........................ 81

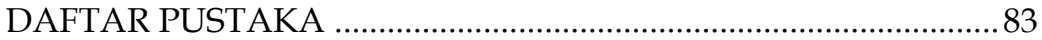




\section{BAB I \\ PENDAHULUAN}

Pada zaman modern ini, tidak ada yang lebih penting kecuali Administrasi Publik. Bila kita cermati secara seksama, adigium tersohor ini ternyata bukan sekedar basa-basi. Sejak kelahirannya pada akhir abad 19, bidang administrasi publik telah menjadi obyek studi ilmiah dari para cerdik cendekia yang berasal dari berbagai disiplin ilmu. Seperti saat ini tantangan yang tengah dihadapi administrasi publik adalah globalisasi.

Globalisasi mengakibatkan terjadinya perubahan dalam manajemen dan perubahan peran dan tantangan manajer dalam menjalankan tugas dan fungsinya. Globalisasi bagi sebuah korporat membawa konsekuensi perhatian akan keseimbangan perspektif global dengan fleksibilitas lokal.

Globalisasi juga membuat organisasi-organisasi lokal harus tetap waspada terhadap perubahan dan perkembangan global yang berlangsung cepat dan terus menerus agar dapat mempertahankan keberadaannya dan untuk mencapai tujuan organisasinya..

Perubahan-perubahan dan tuntutan sosial, ekonomi. politik dan lingkungan sektor publik yang semakin berkembang dan bervariasi telah memberikan tekanan-tekanan terhadap upaya mereformasi administrasi publik melalui gerakan New Public Management ( Wijaya, 2007 ).

Agar dapat mempunyai keseimbangan perspektif global dengan fleksibilitas lokal serta sejalan dengan perubahan dan tuntutan tersebut, salah satu yang harus diperkuat adalah adanya budaya korporat yang kuat yaitu sebuah budaya yang diterima, dipahami, dan dijalankan oleh semua anggota korporat.

Hal tersebut perlu disadari karena menurut Schein dalam Hatch ( 1997 ), bahwa arti penting budaya korporat menjadi sangat besar bagi kelangsungan hidup organisasi terutama bila dikaitkan dengan upaya organisasi untuk mengatasi berbagai masalah 
dalam adaptasi atas berbagai perkembangan dan perubahan eksternal dan integrasi terhadap kekuatan internal. Budaya korporat dapat memiliki pengaruh yang bermakna pada sikap dan perilaku anggota-anggota organisasi. Budaya yang kuat juga sering membantu prestasi kerja usaha karena mereka menciptakan tingkat motivasi yang tidak biasa. Terkadang perasaan tersebut membuat karyawan saling berbagi nilai dan perilaku mereka serta membuat mereka merasa nyaman atau cocok dengan lingkungan kerja di organisasi tersebut, merasa komit atau loyal serta membuat orang bekerja lebih keras, dan menganggap bekerja sebagai sesuatu yang menarik ( Kotter dan Haskett, 1992 ).

Budaya Korporat atau istilah lainnya adalah Budaya Organisasi, tidak begitu saja ada, tetapi harus diciptakan, dipelihara, dan diperkuat, bahkan diubah agar sesuai dengan tuntutan internal maupun eksternal organisasi. Bahkan menurut Hatch ( 1997 ), model dinamika budaya menyatakan bahwa budaya tidak pernah berhenti berubah, melainkan perubahan itu secara dinamis harus berlanjut. Hal ini berkaitan karena isi dari suatu budaya korporat terutama berasal dari tiga sumber, yaitu pendiri organisasi dengan nilai yang kuat dan visi-misi yang jelas tentang bagaimana organisasi seharusnya, pengalaman organisasi menghadapi lingkungan eksternal dan karyawan dalam hubungan kerja mereka. Dan yang perlu disadari adalah bahwa budaya korporat merupakan mekanisme pembuat makna dan kendali yang memandu dan membentuk sikap serta perilaku karyawan.

Paradigma budaya korporat telah bergeser. Budaya Korporat tidak hanya dipandang sebagai warisan masa lalu tetapi juga harus direkayasa dan ditempatkan sebagai strategic tool untuk mencapai tujuan perusahaan dan sebagai daya saing yang ampuh. Hampir semua aspek pengembangan perusahaan selalu terkait dengan budaya korporat ( Susanto, 2004 ).

Semua organisasi mempunyai budaya korporat yang unik yang membedakan dengan perusahaan atau organisasi lainnya, walaupun ada pula yang memiliki budaya yang lebih kuat daripada yang lain. Budaya korporat bukanlah suatu hal yang mudah untuk dirumuskan, meskipun sebetulnya terasa memiliki 
pengaruh yang nyata. Banyak pihak berusaha mengungkapkan hal yang berkaitan dengan pencitraan dan pengembangan budaya korporat, karena budaya korporat merupakan suatu kekuatan yang tidak nampak, tapi mampu mempengaruhi pikiran, perasaan, pembicaraan maupun tindakan manusia yang bekerja pada organisasi tersebut. Budaya korporat mempengaruhi dasar organisasi atau perusahaan. Budaya ini dapat menghasilkan efek yang sangat mempengaruhi individu dan prestasi kerja, dimana budaya kuat yang positif adalah seperagkat bentuk nilai dan kepercayaan yang menyediakan bangunan dasar yang dapat menginovasi organisasi yang solid dengan rantai komando yang jelas dan fleksibel. Budaya korporat juga merupakan kekuatan yang ampuh untuk menggerakkan para karyawan dalam bekerja, khususnya dalam sebuah lingkungan yang bersaing.

Dalam konteks pemberdayaan sumber daya manusia, agar menghasilkan karyawan yang profesional dengan integritas yang tinggi, diperlukan adanya acuan baku yang diberlakukan oleh suatu perusahaan. Acuan baku tersebut adalah budaya organisasi atau budaya korporat, yang secara sistematis menuntun para karyawan untuk meningkatkan komitmen kerjanya bagi perusahaan.

Budaya korporat pada umumnya merupakan pernyataan filosofis, dapat difungsikan sebagai tuntutan yang mengikat para karyawan karena dapat diformulasikan secara formal dalam berbagai peraturan dan ketentuan perusahaan. Dengan membakukan budaya korporat, sebagai suatu acuan bagi ketentuan atau peraturan yang berlaku, maka para pemimpin dan karyawan secara tidak langsung akan terikat sehingga dapat membentuk sikap dan perilaku sesuai dengan visi dan misi serta strategi perusahaan. Proses pembentukan tersebut pada akhirnya akan menghasilkan pemimpin dan karyawan profesional yang mempunyai integritas yang tinggi. Dapat disimpulkan bahwa dengan melakukan perubahan budaya korporat selain akan menghasilkan sumber daya manusia yang berkualitas, juga akan menjadi penentu sukses perusahaan. Dalam kaitan dengan hal tersebut, Harvey dan Bowin dalam Moeljono ( 2005 ) berpendapat 
bahwa semakin meningkat bukti bahwa hanya perusahaanperusahaan dengan budaya korporat yang efektif yang dapat menciptakan peningkatan produktivitas, meningkatkan rasa ikut memiliki dari karyawan, dan pada akhirnya meningkatkan keuntungan perusahaan.

Penelitiian yang dilakukan oleh John P. Kotter dan James L. Heskett

(1992) menunjukkan bahwa terdapat empat faktor yang menentukan perilaku manajemen suatu perusahaan yaitu budaya organisasi atau korporat; struktur, sistem, rencana, dan kebijakan formal, kepemimpinan; dan lingkungan yang teratur dan bersaing ( Moeljono, 2005 ).

Budaya korporat berada di tempat pertama sebagai faktor yang mengkondisikan faktor-faktor lain. "Sehebat" apakah budaya korporat sehingga ia patut menjadi perhatian ? Penelitian kedua pakar ini menurut Moeljono ( 2005 ) membuktikan empat hal yang prinsipil :

1. Budaya korporat dapat mempunyai dampak yang berarti terhadap kinerja ekonomi jangka panjang

2. Budaya korporat mungkin akan menjadi suatu faktor yang bahkan lebih penting lagi dalam menentukan keberhasilan atau kegagalan perusahaan dalam dasawarsa yang kan datang.

3. Budaya korporat yang menghambat kinerja keuangan jangka panjang cukup banyak, budaya-budaya tersebut mudah berkembang, bahkan dalam perusahaan-perusahaan yang penuh dengan orang-orang yang pandai dan berakal sehat.

4. Walaupun sulit untuk diubah, budaya korporat dapat dibuat agar bersifat lebih meningkatkan kinerja.

Dalam rangka mewujudkan budaya korporat yang cocok diterapkan pada organisasi tersebut, maka sangat diperlukan adanya dukungan dan partisipasi dari semua anggota yanng ada dalam lingkup perusahaan. Para pegawai membentuk persepsi keseluruhan mengenai perusahaan berdasarkan karaakteristik budaya korporat seperti yang ada dalam perusahaan mereka. Persepsi pegawai mengenai kenyataan terhadap budaya 4 
korporatnya menjadi dasar pegawai berperilaku. Dari persepsi tersebut menurut Robbin ( 1996 ) memunculkan suatu tanggapan berupa dukungan pada karakteristik perusahaan yang selanjutnya mempengaruhi prestasi kerja karyawan.

Seperti selalu ditegaskan oleh beberapa pengarang, seperti Robbin (1996) dan Schien dalam Hatch (1997) serta Kotter dan Heskett (1997), bahwa pemimpin mempunyai peran yang sangat penting dalam sebuah organisasi. Keberadaannya dapat membentuk, menguatkan bahkan merubah budaya sebuah organisasi. Schein berpendapat bahwa budaya dipengaruhi oleh berbagai aspek perilaku pemimpin, termasuk contoh-contoh yang diterapkan oleh pemimpin tersebut mengalokasikan imbalanimbalan, dan cara pemimpin tersebut membuat pilihan, promosi, dan keputusan-keputusan memberhentikan orang.

Lebih lanjut Schein (1991 ) mengatakan bahwa budaya organisasi atau budaya korporat mengendalikan pemimpin lebih daripada pemimpin mengendalikan budaya organisasi, melalui filter otomatis yang membiaskan persepsi, pemikiran, dan perasaan manajer. Dasar dan menguatnya budaya menjadi dapat meresap dan mempengaruhi segala pekerjaan pemimpin bahkan dalam berpikir dan merasakan. Mekanisme-mekanisme tambahan untuk membentuk budaya termasuk rancangan struktur organisasi, sistem manajemen, fasilitas, pernyataan formal tentang ideologi, dan kisah-kisah informal, dongeng-dongeng, serta legenda. Kesemuanya tersebut dalam tataran karyawan akan berpengaruh kepada komitmen dan kinerja karyawan.

Demikian juga dalam dunia telekmunikasi telah terjadi perubahan budaya korporat di mana lanskap bisnis telekomunikasi mengalami perubahan yang sangat cepat, uncertain, dan turbulen baik dari sisi teknologi, regulasi, pasar, maupun persaingan. Dari sisi teknologi kita melihat munculnya fenomena konvergensi digital ( digital convergen ) yang ditandai oleh bersatunya teknologi pengolahan data (computing), teknologi content dan multimedia digital, dan teknologi telekomunikasi. Konvergensi ini menjadikan batas-batas industri di ketiga sektor ini menjadi kabur dan tumpang tindih. 
Dari sisi regulasi kita melihat munculnya tiga perubahan yang tak kalah signifikannya. Pertama adalah gelombang privatisasi, Incumbent operator di berbagai negara. Kedua, pembukaan pasar dan perubahan paradigma pengelolaan otoritas telekomunikasi dari pendekatan monopoli ( monopolistic approach) menuju ke pendekatan yang lebih pro-pasar. Ketiga, pembentukan badan regulasi independen yang menjamin agar industri iini selalu di dalam rel kompetisi yang sehat dan fair.

Dari sisi lingkungan persaingan telah terjadi hypercompetition akibat pembukaan pasar di industri ini ditandai dengan munculnya pemain-pemain baru dalam jumlah besar dengan strategi yang semakin canggih. Di samping itu, tren konvergensi digital juga telah memunculkan latent competitor yang seringkali sulit teridentifikasi oleh incumbent operator yang ada.

Sementara dari sisi pasar, pembongkaran monopoli dan pembukaan pasar juga telah memicu kecenderungan semakin meningkatnya bargaining position pelanggan di depan operator. Dengan kecenderungan ini tak bisa tidak, para operator harus semakin fokus kepada pelanggan dan harus mampu memberikan paket-paket solusi terhadap setiap persoalan mereka. Akibatnya, customization kemudian menjadi new role of thegame di industri ini yang menentukkan kesuksesan setiap pemain.

Menghadapi perubahan lingkungan bisnis yang berubah cepat di atas, PT. TELEKOMUNIKASI INDONESIA, ( TELKOM ) melakukan berbagai llangkah strategis untuk mengamankan sekaligus memperkokoh daya saingnya di llingkungan bisnis yang baru. Langkah strategis pertama adalah merubah dan merumuskan visi-misi korporat yang baru yang akan memberikan strategic guidelines bagi seluruh karyawan mengenai tujuan akhir tranformasi TELKOM.

Rumusan visi baru tersebut adalah To become a leading InfoCom playerin theregion. Sementara rumusan misinya adalah, TELKOM menjamin bahwa pelanggan akan mendapatkan layanan terbaik, berupa kemudahan, kualitas produk, kualitas jaringan, dengan mengoptimalisasikan SDM yang unggul, penggunaan teknologi yang kompetitif, serta membangun kemitraan yang 6 
menguntungkan secara timbal balik dan saling mendukung secara sinergis.

Perubahan visi-misi tersebut berimplikasi pada perubahan strategi TELKOM secara menyeluruh. Untuk mewujudkan visi menjadi pemain InfoCom terkemuka menggunakan pendekatan customer-centric sebagai grand strateginya. Pilihan ini diambil karena era konvergensi digital ternyata menghasilkan rule of the game baru di mana sukses pemain tak lagi hanya terletak pada kapabilitas penguasaan teknologi, kepemilikan jaringan, atau kemampuan memproduksi layanan, tapi di atas itu semua adalah kemampuan dalam memahami kebutuhan, problem,dan harapan pelanggan.

Jadi paradigmanya dibalik, bukan lagi asset-based orientation tapi customer-centric orientation. Untuk menjadi customer-centric organization maka seluruh operasi TELKOM harus mampu memberikan paket layanan yang customized dan merupakan solusi bagi setiap permasalahan pelanggan.

Perubahan paradigma operasi dari asset-based ke customer based tentu saja menuntut perubahan mindset dan cara kerja seluruh karyawan TELKOM dari level manapun. Karena itu untuk merealisasikan visi tersebut TELKOM juga melakukan tranformasi manusia yang diwujudkan dalam bentuk perubahan budaya korporat. Dengan totalitas sponsorship dari kalangan manajemen puncak, dimulai tahun 2003 lalu TELKOM mengimplementasi budaya korporatnya yang baru THE TELKOM Budaya Korporat ini memegang peran krusial untuk mengikis habis budaya birokratik dan membawa manusia TELKOM lebih berorientasi ke pelanggan (Kartajaya,dkk,2004).Hal ini sejalan dengan yang disampaikan oleh Pierre seperti yang dikutip dalam Wijaya(2007),

yang menyebutkan perspektif New Public Management mempromosikan marketisasi ( Marketization ) sektor publik, penggunaan manajemen kontrak, privatisasi, membuka alternatifalternatif pelayanan sehingga konsumen mempunyai pilihan.

Perspektif ini mereformasi pendekatan manajemen pelayanan publik sebelumnya yang menggunakan pendekatan birokrasi Weberian. King and Maddock membagi tiga model 
dasar untuk public utility yang bercirikan bisnis infrasrtuktur. Model pertama, perusahaan yang beroperasi adalah dibawah pemerintah dan dibawah kontrol politik, disebut Perusahaan Negara /Publik. Model Kedua, perusahaan privat diijinkan mengoperasikan perusahaan publik milik pemerintah namaun mereka diatur dengan regulasi yang ketat untuk mencegah penyalahgunaan wewenang dikarenakan mempunyai hak-hak monopoli pengelolaan bisnis. Model Ketiga, perusahaanperusahaan privat diijinkan berkompetisi untuk mendapatkan hal monopoli mengelola suatu wilayah ( Wijaya, 2007 ). Menurut model dasar untuk public utility yang disampaikan King and Maddock tersebut TELKOM termasuk model pertama karena TELKOM merupakan Badan Usaha Milik Negara yang beroperasi dibawah pemerintahan dan kontrol politik.

Nilai-nilai dasar yang dipegang teguh dan diyakini oleh semua orang di dalam organisasi terbukti menjadi tulang punggung keunggulan bersaing perusahaan. Bahkan dapat disimpulkan bahwa nilai-nilai dasar inilah yang menjadi penentu utama kenapa perusahaan seperti IBM mampu bertahan memimpin pasar selama puluhan bahkan ratusan tahun.

Barangkali karena begitu penting dan krusialnya peran budaya korporat bagi kesuksesan perusahaan, pimpinan TELKOM Bapak Kristiono tidak mendelegasikan upaya membangun budaya korporat THE TELKOM WAY 135 (TTW 135) kepada siapa pun. Beliau maju sendiri di garis depan untuk merumuskan budaya baru TELKOM, merencanakan implementasinya, dan kemudian mengeksekusi penerapannya di jantung operasi TELKOM di seluruh tingkatan organisasi.

Mantan CEO TELKOM Bapak Kristiono, pada saat awal terbentuknya Budaya Korporat The TELKOM Way 135, memposisikan diri sebagai Panglima Perang Budaya Korporat untuk mendorong agar nilai-nilai di dalam TTW 135 bisa terimplementasi secepat seperti diinginkannya. Dan tak hanya itu, ia juga secara langsung memainkan peran sebagai "rule model" untuk pelaksanaan nilai-nilai yang ada dalam TTW 135 ( Kartajaya, dkk, 2004 ). 
TTW 135 adalah budaya dari TELKOM yang satu yang merupakan peleburan dari budaya-budaya yang berkembang subur di Divre tersebut. Secara umum TTW 135 mencakup tiga tingkatan unsur sebagai berikut: Yang pertama, adalah Asumsi Dasar, yaitu tanggapan ataupun pandangan dasar yang menentukan bagaimana insan TELKOM mempersepsi ,berpikir, dan merasakan sesuatu. Anggapan atau pandangan ini diterima tanpa perlu mempertanyakan lagi kebenarannya. Esensi budaya TELKOM terletak pada asumsi dasar ini. Kedua, Nilai-Nilai, yaitu apa yang dianggap penting, apa yang sebaiknya, atau apa yang berharga. Dan ketiga adalah Artefak, Perilaku, mencakup bendabenda, simbol, upacara dan seremoni, tingkah laku ( Kartajaya, dkk 2004 ).

Asumsi dasar adalah komponen yang terdalam dari budaya. Sedangkan nilai dan perilaku merupakan manifestasi yang lebih konkret dari asumsi dasar, bahkan artefak bisa dilihat dan dirasakan. Dengan demikian, dalam model budaya TELKOM ada kaitan yang tidak terpisahkan antara asumsi dasar, nilai-nilai, dan artefak serta perilaku. Ketiganya harus dilihat dan diperlakukan sebagai suatu kesatuan yang utuh dan terpadu.

Dalam model Budaya Korporasi TELKOM, Committed 2U adalah asumsi dasar dan keyakinan yang senantiasa harus diteguhkan oleh setiap insan TELKOM di dalam hati mereka. Unsur ini intinya ingin meneguhkan bahwa hanya dengan komitmen untuk memberikan yang terbaik kepada stakeholders (terutama pelanggan, karyawan, pemegang saham, pemerintah, dan mitra bisnis) TELKOM akan mampu mempertahankan keunggulannya di tengah perubahan lingkungan bisnis yang semakin cepat.

Hati yang sudah diteguhkan, ditindaklanjuti dengan merajut pikiran bahwa hanya dengan orang yang kompeten ( competent people), yang dapat memberikan pelayanan yang istimewa ( excellen service) dan meningkatkan nilai bagi pelanggan ( customer value ) maka memberikan yang terbaik kepada para stakeholders itu bisa tercapai. Karena itu ketiganya 
dijadikan sebagai nilai-nilai inti ( Core Values ) dan keseluruhan nilai-nilai yang dikembangkan perusahaan.

Hati yang sudah diteguhkan dengan Commited 2 U, pikiran yang sudah dirajut dengan 3 nilai inti Competent People, Excellent Service dan Customer Value masih harus diikuti dengan menyerasikan langkah yaitu perilaku semua insan TELKOM untuk pada akhirnya sampai pada pemberian yang terbaik kepada para stakeholders. Kelima langkah yang harus diserasikan adalah sebagai berikut : Stetching the Goals, Simplify, Involve Everyone, Quality is My Job, Rewards the Winners.

Maka dengan unsur satu hati ( Asumsi Dasar ), tiga pikiran ( Nilai Inti ), dan lima langkah ( Perilaku ) tersebut, ingin ditegaskan ulang bahwa Budaya TELKOM mengandung maksud untuk Meneguhkan Hati, Merajut Pikiran, dan Menyerasikan Langkah semua insan TELKOM dalam berkiprah untuk memenangkan persaingan di bisnis Infocom. Inilalh The TELKOM Way 135, Budaya TELKOM yang harus menjiwai seluruh insan TELKOM kedepan. Budaya Korporat yang memberi karakter khas TELKOM dan menjadi salah satu penentu daya saing Perusahaan kedepan.

Singkatnya, apa yang melatarbelakangi perlunya budaya korporat TTW 135 adalah perusahaan ini telah bergerak dari product centric/ asset based ke customer centric company sementara penataan/ pengelolaan perusahaan harus segera dibenahi sesuai tujuan tersebut, persaingan di bisnis infocom sangat kuat sehingga perusahaan ini harus dapat mengadaptasi diri sesuai eranya, dari hasil survey perusahaan ini dalam beberapa kriteria dipresepsi lebih buruk dari pesaingnya padahal TELKOM punya potensi luar biasa besar dibanding pesaing, sehingga salah satu yang dilakukan TELKOM adalah meningkatkan pemahaman terhadap budaya The TELKOM serta mengimplementasikannya dalam aktivitas sehari-hari. 


\section{BAB II \\ GAMBARAN UMUM \\ PT. TELKOM INDONESIA}

\section{A. Sejarah Singkat PT. TELKOM INDONESIA}

PT. TELKOM Indonesia, pada tahun1882 merupakan sebuah badan usaha swasta penyedia layanan pos dan telegrap dibentuk pada masa Pemerintahan Kolonial Belanda. Kemudian pada tahun 1906 Pemerintahan Kolonial Belanda membentuk sebuah jawatan yang mengatur layanan pos dan telekomunikasi yang diberi nama Jawatan Pos, Telegrap dan Telepon. Pada Tahun 1961 status jawatan diubah menjadi Perusahaan Negara Pos dan Telekomunikasi ( PN Postel).

Tahun 1965 PN Postel dipecah menjadi Perusahaan NegaraPos dan Giro ( PN Pos dan Giro ) dan Perusahaan Negara Telekomunikasi ( PN Telekomunikasi ). Pada tahun 1974 PN Telekomunikasi disesuaikan menjadi Perusahaan Umum Telekomunikasi ( Perumtel ) yang menyelenggarakan jasa Telekomunikasi Nasional maupun Internasional.

Tahun 1980 PT. Indonesian Satelite Corporation ( Indosat ) didirikan untuk menyelenggarakan jasa Telekomunikasi Internasional, terpisah dari Perumtel. Berdasarkan UU Nomor 3/ 1989 tentang Telekomunikasi, tentang peran swasta dalam penyelenggaraan telekomunikasi. Pada tahun tahun 1991 Perumtel berubah bentuk menjadi Perusahaan Perseroan ( Persero ) Telekomunikasi Indonesia berdasarkan PP. No. 25 Tahun 1991.

Tahun 1995 merupakan penawaran umum perdana saham TELKOM

( Initial Public Offering/ IPO) dilakukan pada tanggal 14

Nopember 1995 sejak itu saham TELKOM tercatat dan diperdagangkan di bursa Efek Jakarta ( BEJ ), Bursa Efek Surabya ( BES ), New York Stock Exchange ( NYSE ) dan London Stock Exchaange ( LSE). 
Saham TELKOM juga diperdagangkan tanpa pencatatan (Public OfferingWithout Listing/ POWL ) di Tokyo Stock Exchange. Pada tahun 1996 kerja sama Operasi ( KSO ) mulai diimplementasikan pada 1 Jnuari 1996 di wilayah Divisi Regional I Sumatera dengan mitra PT. Pramindo Ikat Nusantara ( Pramindo ), Divisi Regional III Jawa Barat dan Banten dengan mitra PT. Aria West International ( Aria West), ( Dayamitra ), dan Divisi Regional VII Kawasan Timur IIndonesia dengan mitra PT. Bukaka Singtel. Pada tahun 1999 disyahkannya Undang-Undang Nomor 36/ 1999, tentang penghapusan monopoli penyelengaraan telekomunikasi.

\section{B. Korporat The Telkom Indonesia}

\section{Filosofi Dibalik Logo Lebah Biru}

Lebah tergolong makhluk sosial yang senang bekerja sama, pekerja keras, mempunyai kesisteman berupa pembagian peran operasional dan fungsional, menghasilkan yang terbaik berupa madu yang bermanfaat bagi berbagai pihak. Di habitatnya lebah mempunyai dengung sebagai tanda keberadaannya dan loyal terhadap kelompok berupa perlindungan bagi koloninya, maka akan menyerang bersama bila diganggu. Lebah memiliki potensi diri yang baik berupa tubuh yang sehat, liat dan kuat sehingga bisa bergerak cepat, gesit dan efektif dalam menghadapi tantangan alam. Lebah berpandangan jauh ke depan dengan membangun sarang, berproduksi, berkembang biak dan menyiapkan persediaan makanan bagi kelangsungan hidup koloninya. Sedang warna biru merupakan penggambaran insan TELKOM Indonesia.

\section{Arti Kredo Comitted $2 \mathrm{U}$}

a. Kami selalu fokus kepada pelanggan

b. 2. Kami selalu memberikan pelayanan yang prima dan mutu produk yang tinggi serta harga yang kompetitif.

c. Kami selalu melaksanakan segala sesuatu melalui caracara yang terbaik ( Best practices ). 
d. Kami selalu menghargai karyawan yang proaktif dan inovatif, dalam peningkatan produktivitas dan kontribusi kerja.

e. Kami selalu berusaha menjadi yang terbaik.

\section{Arti Logo TELKOM}

a. Bentuk bulatan dari logo melambangkan : Keutuhan Wawasan Nusantara : Ruang Gerak TELKOM secara Nasional dan Internasional.

b. TELKOM yang mantap, modern, luwes, dan sederhana.

c. Warna biru tua dan biru muda bergradasi melambangkan teknologi telekomunikasi tinggi/ canggih yang terus-menerus berkembang dalam suasana masa depan yang gemilang.

d. Garis-garis tebal dan tipis yang mengesankan gerak pertemuan yang beraturan menggambarkan sifat komunikasi dan kerjasama yang selaras secara berkesinambungan dan dinamis.

e. Tulisan Indonesia dengan huruf Futura Bold Italic, menggambarkan kedudukan perusahaan, TELKOM sebagai pandu Bendera Telekomunikasi Indonesia ( Indonesian Telecommunication Flag Carrier )

\section{Visi Korporasi}

TELKOM bukan lagi perusahaan yang memonopoli pasar telekomunikasi Indonesia. Sejak karpet globalisasi digelar, kompetisi menjadi ajang yang harus dijalani oleh perusahaan manapun. Masing-masing akan memperebutkan perhatian kastamer. Yang paling kompetitif tentu saja yang akan menang.

Menjadi Infocom Player mengandung arti bahwa TELKOM bergerak dalam bisnis informasi dan komunikasi yang secara konkret diwujudkan dalam bentuk keragaman produk jasa. Semula layanan yang disajikan hanya POTS (Plain Ordinary Telephone Services); kini menjadi PMVIS (Phone, Mobile, View, Internet, Services). 
Dominant Infocom Player in the Region mengandung pengertian bahwa TELKOM berupaya untuk menempatkan diri sebagai perusahaan Infocom berpengaruh di kawasan Asia Tenggara, yang kemudian akan berlanjut ke kawasan Asia, dan Asia- Pasifik. Menjadi perusahaan yang berpengaruh tersebut mengandung arti apabila dibandingkan dengan perusahaan terkemuka pada area bisnis yang sama, di kawasan regional, dengan menggunakan indikator-indikator tertentu, maka kinerja bisnis dan finansialnya akan seimbang, atau bahkan lebih baik lagi.

\section{Misi Korporasi}

To Provide One Stop Services with Excellent Quality and Competitive PriceManaging Business Through Best Practices, Optimizing Superior Human Resource, Competitive technology, and Synergizing Business Partners

Untuk Menyediakan pelayanan Satu Atap dengan Kualitas, Terbaik dan harga bersaing Mengatur Bisnis Melalui Latihan Terbaik Mengoptimalkan Sumber Daya Manusia Yang Utama, Teknologi yang bersaing dan mensinergikan rekan bisnis To provide one stop services with excellent quality and competitive price, artinya TELKOM menjamin bahwa pelanggan akan mendapatkan layanan terbaik, berupa kemudahan, kualitas produk, kualitas jaringan, dengan harga yang kompetitif.

Managing business through best practice, optimizing superior human resource, competitive technology, and synergizing business partners artinya adalah TELKOM akan mengelola bisnis melalui praktek-praktek terbaik dengan mengoptimalkan SDM yang unggul, penggunaan teknologi yang kompetitif, serta membangun kemitraan yang menguntungkan secara timbal balik dan saling mendukung secara sinergis untuk merealisasikan visi korporasi, dan mendukung pelaksanaan misi tersebut diperlukan budaya korporasi yang kuat. 


\section{The Telkom}

Budaya Korporasi yang dikembangkan TELKOM mencakup tiga tingkatan unsur sebagai berikut:

1. Asumsi Dasar. Yakni anggapan atau pun pandangan dasar yang menentukan bagaimana insan TELKOM mempersepsi, berpikir, dan merasakan sesuatu. Anggapan atau pandangan ini diterima tanpa perlu mempertanyakan lagi kebenarannya. Esensi budaya TELKOM terletak pada asumsi dasar ini.

2. Nilai-Nilai. Yakni apa yang dianggap penting, apa yang sebaiknya, atau apa yang berharga.

3. Artefak, Perilaku. Mencakup benda-benda, simbol, upacara dan seremoni, tingkah laku.

Asumsi dasar adalah komponen yang terdalam dari budaya. Sedangkan nilai dan perilaku merupakan manifestasi yang lebih konkret dari asumsi dasar, bahkan artefak bisa dilihat dan dirasakan. Dengan demikian dalam model budaya TELKOM ada kaitan yang tidak terpisahkan antara asumsi dasar, nilai-nilai, dan artefak serta perilaku. Ketiganya harus dilihat dan diperlakukan sebagai satu kesatuan yang utuh dan terpadu.

Dengan menggunakan ketiga unsur yang berbeda tingkatnya itu, maka Budaya Korporasi yang dikembangkan TELKOM dirumuskan dengan 1 (satu) asumsi dasar, 3 (tiga) nilai inti, dan 5 (lima) langkah perilaku sebagai berikut:

Asumsi Dasar : Committed $2 \mathrm{U}$ : Setia/komit

Nilai-Nilai Inti : 1. Customer Value (nilai tambah pelanggan)

2. Excellent Service (Pelayanan terbaik)

3. Competent People ( Karyawan Yang kompeten )

Perilaku : 1. Stretch The Goals (Rentangkan Tujuan

2. Simplify (Sederhanakan)

3. Involve Everyone ( Libatkan semua orang)

4. Quality is My Job (Mutu adalah pekerjaan saya ) 